\title{
Islamic Guidance and Counseling in Developing Religious Practice Transgender
}

\author{
Muhammad Ali Bagas ${ }^{1}$ \\ 1, Postgraduate UIN Walisongo, Semarang, Indonesia \\ Correspondingauthor :muhammadalibaggaz@gmail.com
}

\section{ART ICLE IN F O}

\section{Article history:}

Received may 2021

Revised june 2021

Accepted july 2021

Keywords:

Islamic Guidance and

Counseling,

religious practice,

transgender

\begin{abstract}
A B S T R A C T
The research aims to describe the guidance counseling Islam in developing religious practice counselees (transgender), by using research libraries in the search for sources that are relevant to the research and using content analysis as a technique for analyzing sources that exist, thus generating appropriate conclusions. The results showed that the guidance and Islamic Guidance and Counseling in developing religious practice counselees (transgender) guided by the provisions contained in it, namely; carrying out the stages, obeying and applying existing principles, to evaluating the guidance and Islamic Guidance and Counseling itself, that way, Islamic Guidance and Counseling as a development medium will be able to realize religious practice and its impact on the counselee (transgender) concerned.
\end{abstract}

(C) IJAGC 2021, All right reserved ISSN: 2722-2365 (Online) 2722-2357 (Print)

\section{Introduction}

Transgender is defined as a term to indicate a man who in everyday life generally resembles the behavior of a woman (Riyadi et al., 2013). In terms, transgender or womenmen are generally said to be men who tend to dress and behave like women (Pujileksono, 2005). Physically, they are born as someone who is male, but their psychological state makes them transform into women in their daily lives (Abidin \&Djabbar, 2019).

Negative stereotypes from the public can still be said to be still attached to these people, for example, regarding attitudes, behavior, and appearances which are generally like women, which are often considered by some people as jokes which then give birth to a kind of bullying against them (Ida, 2010), as in several studies that said, according to Kurnia, et al in their research described several problems related to transgender people, including; problems of social life (related to ridicule, insults, and ridicule, as well as violence, and exclusion) from the people around them which then cause psychological disorders. On the other hand, transgenders have difficulty in obtaining or using an identity card (ID), not being free to use public facilities, and having difficulty in having a professional job. In addition to social 
problems, there are also problems in religion that they feel uncomfortable when joining the male line (Widiastuti et al., 2016).

The survey also noted that in September 2017 there were $40.8 \%$ of people considered LGBT people to be very threatening, while in December 2017 there were $41.4 \%$ of people considered LGBT people to be very threatening (Wibowo, 2018). Mirza \& Rooney, also noted in the results his survey on discrimination against LGBT people in America, published on January 18, 2018, includes; there were 8\% (respondents in the year before the survey) and 29\% (respondents in the last year) of LGBT people reported being refused by doctors or health care providers to meet, due to their sexual orientation and gender identity (Mirza \& Rooney, 2018).

Starting from a stereotype, a negative stigma emerged from the community which then led to social discrimination and spiritual intimidation (Genia Teresia, 2019). Therefore, appropriate and humanist solutions are needed to develop transgender religious practice itself. One solution in developing this aspect of transgender, namely the provision of Islamic Guidance and Counseling (Basit, 2017), which can serve to provide assistance to transgender people as the objectives in Islamic Guidance and Counseling itself, namely; improve faith, Islam, and Ihsan to become a complete person (kaafah).

\section{Islamic Guidance and Counseling}

Guidance counseling comes from two words combined into one. Guidance is a translation that contains several meanings, namely; to direct, to pilot, to manage, or to steer (Anwar, 2019) while counseling comes from the word "counselium", which is interpreted together or talking together, the notion of talking together referred to in this context is a conversation between the counselor and the counselee or several counselees (Latipun, 2015).

The word Islam in the context of guidance and counseling refers to an approach. Islam is a religion that is based on Allah's instructions in the Qur'an and the Hadith of the Prophet Muhammad (Rassool, 2016). Riyadi\&Wigati in their research said that Islamic Guidance and Counseling model was developed based on the Qur'an and Hadith as a guide in guidance and counseling (Riyadi\&Wigati, 2019).

Islamic Guidance and Counseling in its implementation has several stages that must be carried out, these stages consist of the initial stages to the most recent stages. The initial stage (defining the problem), in the early stages, begins with an introduction or ta'aruf, building a good relationship with the counselee (Mashudi, 2019). The key to success in building good relationships lies in the fulfillment of existing principles (Kusnawan, 2020). In addition, there is a process of explaining the problem of the counselee (transgender), making interpretations and preliminary investigations, and there is room for contract negotiations between the counselor and the counselee (Mashudi, 2019).

The Core Stage (the working stage), the core stage, is the understanding stage (hikmah aqliyah), which includes a series of activities, exploring and exploring the counselee's problems, the counselor and the counselee conducting reassessment, reviewing the problems being experienced by the counselee (Mashudi, 2019). At this stage, a counselor tries to convince the counselee about the understanding, teachings that exist in Islam itself, for example regarding the commands and prohibitions of Allah SWT that must be obeyed (Kusnawan, 2020). 
In the final stage (action stage), the final stage, or the amaliyah stage, some things need to be done, including; evaluate the course of the process and results, the counselor makes conclusions with the counselee regarding the results, (Mashudi, 2019) explores the counselee's need for ongoing support, helps the counselee to identify resources and sources of support, supports the counselee in developing and monitoring action plans, the counselor encourages and assists the counselee practicing religious teachings and values correctly, as well as encouraging and helping counselees to understand and practice faith, Islam, and ihsan (Kusnawan, 2020).

Evaluation or muhasabah is the last process in Islamic Guidance and Counseling. Evaluation is needed as an assessment of the results of an outcome, namely; whether there is a decrease in symptoms in the counselee, or whether the counselee has acquired a skill to solve the problem. Therefore, evaluation is important because there is an opportunity for the continuation of the counselee's psychosocial and spiritual development (Rassool, 2019)

Follow-up, if the process of Islamic Guidance and Counseling for a while is deemed sufficient and the results are known, the counselor can still carry out a follow-up process that is preventive, preservative, curative, and development. This action is intended so that the development of faith, Islam, and the counselee's ikhsan does not return to its previous state, and that development is increasingly flourishing near perfection while avoiding damage.

Islamic Guidance and Counseling have several methods that can be applied in increasing awareness of religious behavior or behavior in counselees who are experiencing pressure in their lives, are involved in deviant or criminal behavior (Abdullah, 2020), or to develop the potential of the counselee (Amin, 2016):

a. Non-directive method

The non-directive method or method that is not directed and centered on the counselee (Rassool, 2019) is an Islamic Guidance and Counseling method that originates from a basic belief about humans themselves. The basic belief in question is that humans include; has the right to determine the course of his own life and has a strong power to develop himself. In this method, the counselor does not fill the counselee's mind with a variety of new considerations, but only facilitates the counselee's self-reflection process in an atmosphere of communication full of mutual understanding and warmth (Amin, 2016).

b. Directive Method

The directive method or method is directive and centered on the counselor (Rassool, 2019). Counselors in this method, only try to direct the counselee to overcome the problems that are being faced. The direction given to the counselee, namely; in the form of providing direct answers about the various problems that are the cause of the problems experienced by the counselee itself.

c. Elective Method

The eclectic method, this method is said to be a method of combining elements that exist in non-directive and directive methods (Amin, 2016). In this method, the counselor is required to have a high degree of flexibility to adapt the theory or model to each counselee, or in another language, the counselor must be able to choose the best or most appropriate ideas and techniques from various theories and models, to meet the counselee's needs (Rassool, 2019). 


\section{d. Integrative Method}

An integrative method is a method that unites existing theories or models into new theories or models. In this method, the counselor tries to unite elements from various existing theories and models into a new theory or model, namely; to combine different theories in an integrative framework, then apply the integrative model that has been made in practice (Rassool, 2019).

The four methods that have been described above, each method has its characteristics in dealing with the counselee. Through these characteristics, each method can be used to assist the counselee to solve the problems at hand, and the four methods depend on the conditions and circumstances of the counselee itself. Therefore, no method can be said to be good or bad, it all depends on the conditions and circumstances of the counselee (transgender) who will be helped to solve the problems he is facing.

\section{Religious Practice Concept}

Religious practice is two words that come from English, namely "religious" which means piety or obedience, and "practice" which is interpreted as implementation or practice, which when viewed from an Islamic point of view, namely religious practice can be termed as "taqwa" and has the meaning of maintaining and keeping (Saichon, 2017). Religious practice (taqwa) itself, has a close relationship with religion and has various meanings. Religious practice is an attempt to avoid Allah SWT punishment by obeying what He commands and staying away from what He forbids (Bhatti et al., 2015).

Religious practice is related to religious rituals, such as ablution, reading the Qur'an, tawaf, nuzulul Qur'an, lailatulqadar, the birthday of the Prophet, Eid al-Fitr, and other forms of celebrations, all of which are not just routine alone, but contains a symbolic meaning that leads to devotion to Allah SWT (Ulya, 2013).

Furthermore, Quraish Shihab describes the religious practice, relating to polite manners towards Allah SWT, the Messenger of Allah SWT, fellow humans, animals, plants, the natural environment, and inanimate objects, all of which are sourced from the Qur'an and, sayings, attitudes, and examples of the Prophet Muhammad PBUH, or from the culture of the local community that does not conflict with the values of the Qur'an and Sunnah (Shihab, 2019).

From several existing views, it can be concluded that religious practice is something that is oriented towards individuals in carrying out the values and teachings that exist in the religion they believe in everyday life or can also be described as a form of individual obedience to religion. what they believe in (Zarkasyi, 2014) or in another meaning, namely; an impact or consequence that is born of individual religion regarding the values and teachings of the religion they believe in, for example praying, fasting, going on the pilgrimage to Mecca if they are able, caring for others and applying the teachings and values of other religions (Kolb \& Yildiz, 2019).

\section{Method}

This paper will try to describe a formulation of the pattern of Islamic Guidance and Counseling in developing the religious practice of the counselee (transgender) using library research. Library research is a type of research that only searches for library materials, such 
as books, journals, magazines, newspapers, reports, and other types of archives and other documents that can be used as data in research (Zed, 2014). As for the techniques used in analyzing the problem, namely; content analysis, which is said to be an analytical technique in research that utilizes procedures to draw valid conclusions from an existing book or document.

\section{FindingsandDiscussion}

Transgender people are humans as well as citizens and the people of Indonesia who basically both need or need motivation, direction, and advice ( $\left.d a^{\prime} w a h\right)$ like humans and the Indonesian people in general, especially in the aspect of religious practice (Kusnawan, 2020), such as performing ablution. prayer, reading the Qur'an, sholawat, dhikr, and other worship rituals, as well as understanding and knowledge of religious values and teachings to get closer to Allah SWT, which can then direct them to behave and behave under religious teachings (Badruzanan, 2017).

Looking at this aspect, the development of the counselee's (transgender) religious practice through Islamic Guidance and Counseling, can be one solution regarding the transgender religious practice aspect in Indonesia. Because Islamic Guidance and Counseling are one of the development media that is closely related to religious values and instructions (Ansori et al., 2019), as stated by Kania, et al, that; the values that exist in religion, can provide a mechanism of control to have internal awareness when they want to take actions that deviate from human nature itself (Kania, 2019).

Therefore, when referring to this opinion, it is not wrong to say that; the development of religious practice through Islamic Guidance and Counseling can provide a more appropriate approach pattern to be used to develop religious practice towards transgender so that it can provide better for the counselee (transgender), both personally and socially, as the basic purpose of Islamic Guidance and Counseling, namely; increase faith, Islam, and ihsan, so that the counselee (transgender) can control himself in dealing with problems and is not easy to experience stress, depression, frustration or other psychological disorders and can protect himself from things that can harm himself and others, as the picture contained in the frame of mind.

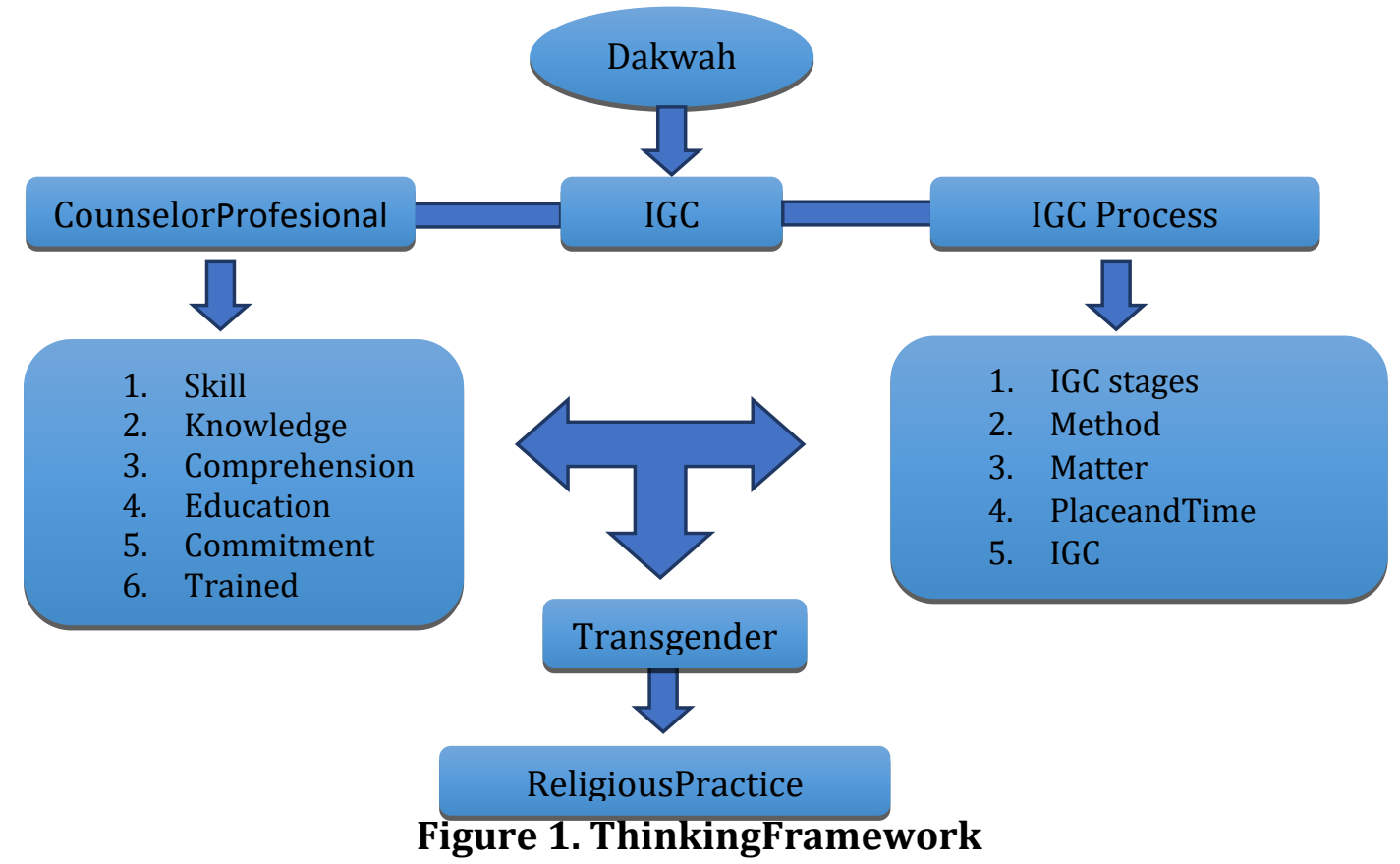




\section{Conclusion}

The issue regarding the development of transgender religious practice or transgender people, which can be said to be rarely noticed and looked at, is a problem that requires an appropriate and humanist solution, especially in Indonesia as a democratic country based on Pancasila. Islamic Guidance and Counseling can be said to be one of the right solutions to this problem. Because basically, Islamic GuidanceandCounseling can function as a medium to assist transgender people in developing these aspects (either individually or in groups) in a more structured and well-conceived manner.

Therefore, Islamic Guidance and Counseling as a medium for developing religious practice for the counselee (transgender) must be carried out by taking into account the things that have become provisions that must be followed (for example, referring to the stages of counselee guidance, obeying and applying the principles of guidance and counseling). , and so on until the evaluation stage of guidance and counseling) because basically, it is a guideline to achieve a result expected by the counselee or the counselor himself, which in this context focuses on the development of religious practice and its impact on transgender or known as transgender. Studies on Islamic Guidance and Counseling related to transgender or transgender, especially those in Indonesia itself, must continue to be carried out so that later they will be able to produce more appropriate and wise approaches in addressing transgender issues in Indonesia, because in the future Basically, Islamic Guidance and Counseling have formulas that can be used as wiser guidelines for transgender issues, especially in Indonesia.

\section{References}

Abdullah, R. (2020). Model of Islamic Guidance and Counseling in Developing Religious Behavior and Interest of Leading Islamic Religious Former Recidivist in Padepokan Maung Bodas Ciamis Foundation. Diadikasia Journal, 1(1).

Abidin, K., \&Djabbar, Y. (2019). AnalisisInteraksiSimbolik Transgender (Wanita Transgender) di Makassar - Indonesia Timur. Society, 7(2), 212-230.

Amin, S. M. (2016). Bimbingan dan Konseling Islam. Amzah.

Ansori, I. H., HubbahHarisah, N., Fathan Asyrofi, M., \&KhoirulRooziqiin, A. (2019). PsikologiShalat (Kajian Tematik Ayat-Ayat Shalat dengan Pendekatan Psikologi Perspektif Muhammad Bahnasi). Journal of Ethics and Spirituality, 3(1).

Anwar, M. F. (2019). Landasan Bimbingan dan Konseling Islam. Deepublish.

Badruzanan, A. (2017). KesalehanSosial di Balik Ketaatan. Elex Media Komputindo.

Basit, A. (2017). Konseling Islam. Kencana.

Bhatti, 0. K., Alkahtani, A., Hassan, A., \& Sulaiman, M. (2015). The Relationship between Islamic Piety (Taqwa) and Workplace Deviance with Organizational Justice as a Moderator. International Journal of Business and Management, 10(4). https://doi.org/10.5539/ijbm.v10n4p136

Genia Teresia. (2019). Kelompok Minoritas Seksual dalam Terpaan Pelanggaran Ham. Lembaga Bantuan Hukum Masyarakat.

Ida, R. (2010). ResponsKomunitas Transgender Surabaya terhadapKonstrukSubjek Transgender di Media Indonesia. JurnalUnair, 23(3).

Kania, D. D. (2019). TransformasiMenuju Fitrah LGBT dalamPerspektifKeindonesiaan. Yayasan DompetDhuafaRepublika\& AILA Indonesia. 
Kolb, J., \& Yildiz, E. (2019). Muslim everyday religious practices in austria. From defensive to open religiosity. Religions, 10(3), 1-15. https://doi.org/10.3390/rel10030161

Kusnawan, A. (2020). BimbinganKonseling Islam BerbasisIlmuDakwah. SimbiosaRekatama Media.

Latipun. (2015). PsikologiKonseling (Keempat). UMM Press.

Mashudi, F. (2019). PsikologiKonseling. IRCISoD.

Mirza, S. A., \& Rooney, C. (2018, January). Discrimination Prevents LGBTQ People From Accessing Health Car. Center of American Progress.

Pujileksono, S. (2005). Transgender dan TekananSosial. UMM Press.

Rassool, G. H. (2016). Islamic Counselling an Introduction to Theory and Practice. Routledge.

Rassool, G. H. (2019). Konseling Islami Sebuah PengantarKepada Teori dan Praktik. Pustaka Pelajar.

Riyadi, A. K., Faidah, M., \& Abdullah, H. (2013). Religiusitas Dan Konsep Diri Kaum Transgender. Jsgi, 04(01).

Riyadi, A., \&Wigati, Y. I. (2019). Model Structure of Islamic Guidance and Counseling in the Healing Process of Inpatients. JurnalBimbingan Dan Konseling, 6(2).

Saichon, M. (2017). Makna Taqwa dan Urgensinya Dalam Al-Qur'an. JurnalUsrah, 3(1).

Shihab, M. Q. (2019). Islam Yang Saya Anut. Lentera Hati.

Ulya. (2013). RitusdalamKeberagamaan Islam: RelevansiRitusdalamKehidupan Masa Kini. JurnalIImu Aqidah Dan Studi Keagamaan, 1(1), 195-206.

Wibowo, D. N. \& K. S. (2018). Pernyataan Soal LGBT TimbulkanPolemik, Zulkifli Hasan Menghindar. Tempo.Com.

Widiastuti, S. K., Risakotta, F. A., \&Syamsiyatun, S. (2016). Problem-Problem Minoritas Transgender dalamKehidupanSosialBeragama. JurnalIImiahSosiologi Agama Dan PerubahanSosial, 10(2).

Zarkasyi, I. (2014). Usuluddidn (Aqa ïd): Ala Madzhab Ahli-s-Sunnah Wal-l-Jama`ah`. Trimurti Press.

Zed, M. (2014). Metode PenelitianKepustakaan. Yayasan Pustaka Obor Indonesia. 